\title{
Contrastive of Aspect and Mood Between Japanese and Bahasa Indonesia in Minna no Nihongo
}

\author{
Irma Qurrota A'yun \\ Universitas Negeri Surabaya \\ Surabaya, Indonesia \\ irma.17070835011@mhs.unesa.ac.id
}

\author{
Roni \\ Universitas Negeri Surabaya \\ Surabaya, Indonesia \\ roni@unesa.ac.id
}

\begin{abstract}
Aspect and mood are a unity connected because of verbs. Aspect are related to the timing and meaning of an event, shown by verbs. Whereas, mood are related to the speaker's attitude to what he is saying and marked by the verb. The change of verb (morphologically) is one of the signs of aspect and mood. Meanwhile, another way is by adding another part of speech (auxiliary) before verb (periphrastic). The purpose of this research is for contrasting the change of verb's form in aspect and mood between Japanese and Bahasa Indonesia. In Japanese, the sign of aspect and mood more frequently applies morphologically. However, in bahasa Indonesia, the signs of aspect and mood is fairly distinctive to Japanese, in which, they apply more periphrastically, even, it is often unsigned, and is only emphasized with time signals. In this research, there were 5 aspects which were perfective-imperfective aspect, resultative aspect, durative aspect, progressive aspect, habituative aspect, and five moods which were, interrogative, negative, desiderative, irrealist, and imperative-hortative mood between Japanese and bahasa Indonesia.
\end{abstract}

Keywords-contrastive, aspect, mood, Japanese, bahasa Indonesia

\section{INTRODUCTION}

Aspect correlate with timing and the purposes of event, which are signed by verbs. Meanwhile, mood correlates with speaker attitude towards what is going to be uttered and is signed by verbs. Tense, aspect, and mood in some languages can be indicated by some morphological changes on verbs, but in some other languages, it is indicated by another part of speech on verbs, so it turns to be phrasal verb. Therefore, the changes are called periphrastic. Japanese often deals with morphological changes. Meanwhile, bahasa Indonesia often deals with periphrastic changes. It becomes interesting to compare and researched. This research aims to describe how the different forms of changes based on the data.

The theory about aspect and mood is primarily underlain by Verhaar [1]. Meanwhile, another supporting theories are from Comrie [2], Alwi [3], Sutedi [4], and Yoshio, in Darjat [5]. But in this research, there were only five aspects which were perfective-imperfective aspect, resultative aspect, durative aspect, progressive aspect, and habituative aspect. While there were five moods which were, interrogative, negative, desiderative, irrealist, and imperative-hortative mood between Japanese and bahasa Indonesia.

The contrastive of aspect and mood between Japanese and bahasa Indonesia in this research are applied in Minna no
Nihongo. Minna no Nihongo is Japanese textbook that usually used for Japanese learning in a basic level. Minna no Nihongo used as a data resource because the contrastive of aspect and mood that can be found there will help the basic Japanese learner to understand more about the grammar's difference and similarity between Japanese and bahasa Indonesia. So, it will be easier for them to learn the basic Japanese grammar.

There are some research which correlate with this research. The first is coming from Roni [6]. In his article, entitled Hubungan Qualifier dan Penyambung dalam Frasa Predikat Verba (The Correlation of Qualifier and The Connector in Predicative Verb Phrase), he looks from the point of view of the order of morphemes and words in the sentence, entering this aspect and mood as a constituent qualifier. Second, third, and forth research are closer to this research. There are Özbek [7] and DEPCI [8] who tried to do a contrastive research between Japanese and Turkish language, and also Iwamoto [9] who had already done a contrastive research about modality and point of view of Japanese wartime and peacetime.

\section{MEthods}

This research used descriptive qualitative approach, applying contrastive research. The main theory used to solve the problems was Verhaar's theory [1]. That theory was used as a main theory to underlie other theories in order to acquire the differences between Japanese and bahasa Indonesia.

The object in this research was the core of a sentence, which was verbs. Verbs observed was mainly correlated to the changes of verbs stating aspect and mood. In conclusion, the sentences containing pattern change on verbs became the data in this research. The data were taken from the source of data in form of text book, which was Minna no Nihongo volume I and II [10]. This was because Minna no Nihongo had 2 versions, Japanese versions and Indonesian-translated. As a result, the data will be vividly contrasted. As other researches applied, after collecting the data, the researcher will then analyzing and the data and describing the result in sub III.

\section{RESULTS AND DISCUSSION}

\section{A. Aspect}

Aspect is a different way to indicate internal temporary constituent from a situation [2]. In another word, tense was an external time (the time of an event), meanwhile, aspect was an internal time from the tense. Based on Verhaar [1], aspect is 
differentiated into eight kinds. They are initiating aspect or incoative, resolution aspect which are perfective (done) and imperfective (undone), result aspect, which are resultative and non-resultative, durability aspect, which are durative (based on time length) and progressive (sustainable), directed to the progress, repetitive aspect or iterative, habituative aspect, correlative aspect on undivided moments or punctual, and situation aspect or stative (non-changing condition), without process, and without result. But in this research, not all of aspect can be contrasted. There were only five aspect that can be contrasted in this research according to the limit of the research above.

According to the data aspect contrastive analysis in this research can only fulfill grouping types of perfective and imperfective, resultative, durative, progressive, and habituative aspects. Below is the following details.

\section{a) Contrastive Analysis of Perfective and Imperfective Aspect}

Perfective aspect means declaring done or finished action. While the imperfective aspect means declaring undone or unfinished action. Below are the the examples from data:

(1a) もう新幹線の切符を買いましたか。 $(\mathrm{MnN} .1 . \mathrm{J} / 7 / 56)$

Mou shinkansen no kippu o kaimashitaka. 'Have you already bought Shinkansen ticket?'

(1b) Apakah Anda sudah membeli karcis Shinkansen? (MnN.1.I/7/50)

'Have you already bought Shinkansen ticket?'

(2a) レポートはもうできましたか。 (MnN.2.J/31/44)

Repooto wa mou dekimashitaka.

'Have you already finished your report?'

(2b) Apakah Anda sudah menyelesaikan laporan? (MnN.2.I/31/36)

'Have you already finished your report?'

(3a) いいえ、まだ書いていません。 (MnN.2.J/31/44)

Iie, mada kaite imasen.

'No, (I) have not written it yet.'

(3b) Belum, saya belum menulisnya.(MnN.2.I/31/36)

'No, I have not written it yet.'

(4a) すみません。この手紙を書いてしまいます から、お先にどうぞ。(MnN.2.J/29/26) Sumimasen. Kono tegami o kaite shimaimasu kara, osaki ni douzo.

'Sorry. You can go first because I will finish writing this letter.'

(4b) Maaf. Silahkan duluan, karena saya akan menyelesaikan surat ini dulu. (MnN.2.I/29/24) 'Sorry. You can go first because I will finish this letter.'

In the example (1a), perfective aspect is indicated by the verb change (mou) -shita. The pattern of (mou) -shita on the verb mou kaimashita show that the action buying has done. In that example, the occuring change is a combination of morphologic (-shita) and periphrastic (the word addition mou). Meanwhile in the example (1b), perfective aspects indicated by the word sudah before the verb membeli, so the indication occurs periphrastically.

Next, in the example (2a), the analysis is similar to (1a). Perfective aspect is indicated by the verb change (mou) -shita. The pattern (mou) -shita on the verb mou dekimashita show that the action finishing the report has been done. However, because it is interrogative sentece, so the example (2a) contains interrogative mood. Meanwhile, in the example (2b), perfective aspect is stated by the word sudah and the verb menyelesaikan.

Further, in the example (3a), the aspect found was imperfective. The pattern (mada) -te imasen on the verb kaite imasen shows that the action writing has not finished. Meanwhile, in (3b), imperfective aspect is indicated by the word belum that preceed the verb menulis.

In the example (4a), imperfective aspect is indicated by the form -te shimaimasu. That form change show that the action has not finished. Meanwhile in (4b), imperfective aspect is indicated by the word akan, to show unfinished actions. Hence, instead of showing imperfective aspect, the sentence (4b) can also show incoative (the beginning), because of the word akan before the verb.

The meaning (glos) of example (1a) is similar with (1b). It also the same in the example (2a), (2b); and (3a), (3b). But in example (4a) and (4b), the meaning is a bit different. It is occured because there is different verb used in both example (4a) and (4b).

\section{b) Contrastive Analysis of Resultative Aspect}

Resultative aspect states the outcome or the final condition of an activity. The following are the data found:

(5a)この自動販売機は壊れています。 (MnN.2.J/29/26)

Kono jidouhanbaiki wa kowarete imasu. 'This vending machine is broken.'

(5b) Mesin penjual otomatis ini Ø rusak. (MnN.2.I/29/24)

'This vending machine is broken'.

(6a) 交番に町の地図がはってあります。 (MnN.2.J/30/34)

Kouban ni machi no chizu ga hatte arimasu. 'In the police station there is a taped map.'

(6b) Di pos polisi tertempel peta. (MnN.2.I/30/30) 'In the police station there is a taped map.'

In the example (5a), the resultative aspect is represented by -teimasu form in verb kowareteimasu. The changes of that verb is a result of jidouhanbaiki 'the vending machine'. While in example (5b), the resultative aspect is not indicated by anything $(\varnothing)$, but is directly expressed by a word rusak 'broken'. 
Then in example (6a), the resultative aspect is represented by the form of -tearimasu in verb hattearimasu. The changes of that verb is a result of chizu 'map'. While in example (6b), the resultative aspect is represented by morphological changes that is expressed by the prefix ter-in verb tertempel. The verb tertempel in the example has the meaning menjadi tempel, as a result of peta.

The meaning between example number (5a) and (5b), then number (6a) and (6b) are similar. However, although the meaning are similar, but the form of the verb between data in Japanese and data in bahasa Indonesia are different.

\section{c) Contrastive Analysis of Durative Aspect}

Durative aspect states the ongoing activity, or in the other words, the duration of an activity within a certain duration. The example from the data are below:

(7a) わたしは京都へ行きます。(MnN.1.J/5/38)

Watashi wa Kyouto e ikimasu.

'I will go to Kyoto.'

(7b) Saya akan pergi ke Kyoto. (MnN.1.I/5/38)

'I will go to Kyoto.'

(8a) わたしは駅で新聞を買います。 (MnN.1.J/6/46)

Watashi wa eki de shinbun o kaimasu.

'I buy newspaper in the train station.'

(8b) Saya Ømembeli surat kabar di stasiun. (MnN.1.I/6/44)

'I buy newspaper in the train station.'

(9a) 今会議室で松本さんと話しています。 (MnN.1.J/14/114)

Ima kaigishitsu de Matsumoto-san to hanashite imasu.

'He is speaking with Mr. Matsumoto in the meeting room now'

(9b) Sekarang (dia) sedang berbicara dengan Pak Matsumoto di ruang rapat. (MnN.1.I/14/92)

' $\mathrm{He}$ is speaking with $\mathrm{Mr}$. Matsumoto in the meeting room now'

In example (7a), a durative aspect is represented by verb ikimasu. Because the verb ikimasu explains a momentary activity (shunkandoushi), in the other words. in a certain time. While in example (7b), verb akan pergi does not represent durative aspect but it represent incoative aspect because there is a word akan.

In example (8a), durative aspect is represented by verb kaimasu. Because kaimasu is also a part of a verb that explain the activity that only be done in certain time. While example (8b), durative aspect is represented in verb membeli.

Next, in example (9a), durative aspect is clearly represented by -teimasu form in verb hanashite imasu. Because -teimasu in that sentence explaining sustainability within a certain time. Besides, adverb of time ima 'now' strengthen the evidence that sentence (9a) is represent a durative aspect. In line with example (9a), in example (9b), the durative aspect is represented by the word sedang before a verb berbicara. Besides that, the existence of adverb of time sekarang is also strengthen that there is durative aspect in that sentence.

\section{d) Contrastive Analysis of Progressive Aspect}

Progressive aspect states the activities in progress or continue. Below are the data found:

(10a) 家族と友達に書きます。(MnN.1.J/7/56) Kazoku to tomodachi ni kakimasu. 'I will write it to my family and my friends.'

(10b) Saya akan menulisnya kepada keluarga dan teman. (MnN.1.I/7/50) 'I will write it to my family and my friends.'

(11a)（わたしは）富士大学で教えています。 (MnN.1.J/15/122)

(Watashi wa) Fuji daigaku de oshiete imasu. 'I am teaching in Fuji University.'

(11b) Saya $\underline{\emptyset}$ mengajar di Universitas Fuji. (MnN.1.I/15/98)

'I am teaching in Fuji University.'

In example (10a), progressive aspect is represented by a verb kakimasu because it has characteristic as progressive. While in example (10b), additional word of akan before the word menulis is giving impression that there is incoative aspect, not a progressive. But, if we look at the characteristic of the word menulis, it can be said that it is a progressive aspect because there is a continuity in it.

Then, in example (11a), there is progressive aspect in the form-teimasu as it is supported by characteristic of the word oshieteimasu that represent an activity that has a progress. While in example (11b), there is no any clue that represent progressive aspect. However, it is in line with (10b) that the progressive aspect can be identified based on the characteristic of the word mengajar that represents an activity that has a progress.

\section{e) Contrastive Analysis of Habituative Aspect}

Habituative aspect states the repetitive activities in the context of habits. It is also usually reinforced with the adverb of time. Below are the data found:

(12a) わたしは毎朝6時に起きます。 (MnN.1.J/4/30)

Watashi wa mai asa roku ji ni okimasu. 'I wake up every morning at six o'clock.'

(12b) Saya $\underline{\emptyset}$ bangun pada jam 6 (setiap) pagi. $(\mathrm{MnN} .1 . \mathrm{I} / 4 / 32)$

'I wake up every morning at six o'clock.'

(13a) 毎朝ジョギングをしています。 (MnN.2.J/28/18)

Mai asa joginggu o shite imasu.

'I always jogging every morning.'

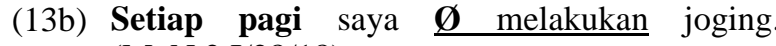
(MnN.2.I/28/18) 
'I always jogging every morning.'

In example (12a), form -masu in verb okimasu can also be used to explain habituative aspect. Besides that, an adverb of time maiasa 'every morning' strengthen the evidence that there is habituative aspect in that sentence. In example (12b), it does not clearly show habituative aspect that represented by a verb (in perifratic way). However, the identification of habituative aspect can be shown with the existence of adverb of time setiappagi'every morning' that explain a habit.

Next, in example (13a), form -teimasu shows habituative aspect because -teimasu can also be used to explain habitual activity. Besides, adverb of time maiasa is also the evidence of habitual activity. While in example (13b), the analysis is same as (12b), habituative aspect is not clearly shown by the verb but it is shown by the existence of adverb of time setiap pagi.

\section{B. Mood}

According to Lyons [3], mood is attitude of speaker to what he/she said. It relates to how a person behaves toward his/her words. According to Verhaar [1], mood can be grouped into five kinds, there were interogative, negative, desiderative, irealist, and imperative-hortative mood. Based on the data found, mood analysis are explained as the following.

\section{a) Contrastive Analysis of Interrogative Mood}

Interrogative mood means asking something, usually a question sentence like "yes/no" question, and also a question that needs a complete answer. The example data as follows:

(14a) 毎朝何時に起きますか。(MnN.1.J/4/35) Mai asa nanji ni okimasuka.

'What time do you wake up every morning?'

(14b) Jam berapa Anda bangun setiap pagi? (MnN.1.I/4/35)

'What time do you wake up every morning?'

(15a) たれにクリスマスカードを書きますか。 (MnN.1.J/7/56)

Dare ni kurisumasu kaado o kakimasuka.

'To whom will you write a Christmast card?'

(15b) Kepada siapa Anda akan menulis kartu natal? (MnN.1.I/7/50)

'To whom will you write a Christmast card?'

(16a) レポートはもうできましたか。

(MnN.2.J/31/44)

Repooto wa mou dekimashitaka.

'Have you already finished the report?'

(16b) Apakah Anda sudah menyelesaikan laporan? (MnN.2.I/31/36)

'Have you already finished the report?'

In example (14a), interrogative mood is indicated by the suffix $-k a$ after the verb okimasu and reinforced by the word nanji which is a question word about a time. The question type that appears in example (19a) is a nonpolar question, which requires an answer to the existing question. If the question is about the clock (time), then the answer should also be about the clock. While in example (14b), the interrogative mood is indicated by the question word jam berapa and the question mark (?). The question type is equal to (14a) as nonpolar.

In example (15a), the interrogative mood is indicated by the suffix - $k a$ after the verb kakimasu and reinforced by the word dare $n i$ which is a question word on to whom/for whom. The question type that appears in example (15a) also includes nonpolar question. While in example (15b), the interrogative mood is indicated by a question word kepada siapa and a question mark (?). The type of question is equal to (15a) as nonpolar.

In the example (16a), the interrogative mood is represented by the suffix $-k a$ after the verbdekimasu. The question type that appears in example (16a) includes a polar question because it only requires answer like yes/no. Whereas in example (16b), the interrogative mood is indicated bythe question apa which is added with klitika-kah so that it becomes apakah and is amplified by a question mark (?). The question type equals (16a) as polar.

The meaning in all of the example between Japanese's data and bahasa Indonesia's data at number (14) until (16) are same. Although the form of the verb may be different.

\section{b) Contrastive Analysis of Negative Mood}

Negative mood means denying a thing, usually shown by negative sentence. The example of the data found are below:

(17a) いいえ、（わたしは）吸いません。 (MnN.1.J/6/46)

Iie,(watashi wa) suimasen.

'No, I do not smoke.'

(17b) Tidak, (saya)tidak merokok. (MnN.1.I/6/44) 'No, I do not smoke.'

(18a) サントスさんはパーティーに来なかった。 (MnN.1.J/20/164)

Santosu-san wa paatii ni konakatta. 'Mr. Santos did not come to the party.'

(18b) Saudara Santos tidak datang ke pesta. (MnN.1.I/20/128)

Mr. Santos did not come to the party.'

In the example (17a), the negative mood is represented by the form -masen (formal) in the verb suimasen. So that the change occurs morphologically (in one word). While in example (17b), the negative mood is indicated by the addition of word tidak before the verb merokok. So the changes take place in a periphrastic manner.

In example (18a), the negative mood is represented by the form-nakatta (informal/past tense) so that the change occurs morphologically. While at (18b), the negative mode is indicated by a word tidak before the verb datang. Negative mood marking occurs periphrastically.

\section{c) Contrastive Analysis of Desiderative Mood}

Desiderative mood basically expressed a desire. Beside that, it can also express the necessity and ability. Example: 
(19a) わたしはパソコンがほしいです。 (MnN.1.J/13/104)

Watashi wa pasokon ga hoshii desu.

'I want a personal computer.'

(19b) Saya ingin punya personal komputer. $(\mathrm{MnN} .1 . \mathrm{I} / 13 / 86)$

'I want to have a personal computer.'

(20a) わたしはてんぷらを食べたいです。 (MnN.1.J/13/104)

Watashi wa tenpura o tabetaidesu.

'I want to eat tempura.'

(20b) Saya ingin makan tempura. (MnN.1.I/13/86)

'I want to eat tempura.'

(21a) ミラーさんは漢字を読むことができます。 (MnN.1.J/18/146)

Miraa san wa kanji o yomu koto ga dekimasu. 'Mr. Miller can read Kanji.'

(21b) Saudara Miller dapat membaca huruf Kanji. (MnN.1.I/18/116)

'Mr. Miller was able to read Kanji.'

(22a) パスポートを見せなければなりません。 (MnN.1.J/17/138)

Pasupooto o misenakereba narimasen.

'We should show the passport.'

(22b) Kita harus memperlihatkan paspor.

$(\mathrm{MnN} .1 . \mathrm{I} / 17 / 110)$

'We should show the passport.'

In the example (19a), there is no desiderative mood marker in the form of a verb but a marker of auxiliary such as 'will' and 'must' in English, it is hoshii (want). But the word hoshii actually can also be categorized into adjectives. Then in example (19b), there is a word ingin which is a definite marker of the desiderative mood. The meaning in example (19a) are a bit different with example (19b). Because there is an additional word punya 'have' in example (19b). But in example (19a), there is no additional word arimasu 'have', so there is only word of hoshii 'want' and no additional word.

Further, in example (20a), the -tai form in the verb tabetai denotes a desiderative mood so the marking occurs morphologically. Whereas in (20b), the word ingin before the verb makan markes the existence of desiderative mood periphrastically.

Then in example (21a), the yomu pattern (basic verb/dictionary form) + koto ga dekimasu indicates a desiderative mood meaning 'can/afford' and the marking occurs morphologically. While in example (21b), the desiderative mood is indicated by the word dapat before membaca. So the marking occurs periphrastically. The meaning between example (21a) and (21b) are a bit different, because the tense between them are a bit different. In example (21a), it is more likely a kind of present tense, but in example (21b), it is more likely past tense.

Last, in example (22a), the desiderative mood means 'should/have to' indicated by a change in the form - nakerabanarimasen as in the verb misenakerebanarimasen so the marking occurs morphologically. Whereas at (22b), the desiderative mood is indicated by the presence of the word harus 'should' before the verb memperlihatkan so the marking occurs periphrastically.

\section{d) Contrastive Analysis of Irrealist Mood}

Irrealist mood means expressing a sense of sanction against a thing. In other word, it shows uncertainty. Example:

(23a) 30分ぐらいで戻るといっていました。 (MnN.2.J/33/60)

Sanjuppun gurai de modoru to itte imashita. 'He said he would be back in about thirty minutes.'

(23b) Katanya akan kembali kira-kira tiga puluh menit. (MnN.2.I/33/48)

'He said he would be back in about thirty minutes.'

In example (23a), irrealist mood is indicated by the pattern -to itteimashita. While in example (23b), irrealist mood marked by katanya 'he said'.

\section{e) Contrastive Analysis of Imperative-Hortative Mood}

Imperative-hortative mood means "have someone to do something". But, if imperative mood more likely to give order/command roughly, then hortative mood more likely to ask for help, so it sounds more subtle. Example:

(24a) ここに住所と名前を書いてください。 (MnN.1.J/14/114)

Koko ni juusho to namae o kaite kudasai.

'Please write down your name and address here.'

(24b) Tolong tulis alamat dan nama Anda disini. (MnN.1.I/14/92)

'Please write down your name and address here.'

(25a) いそげ。(MnN.2.J/33/60)

Isoge.

'Quickly!'

(25b) Cepat-cepat. (MnN.2.I/33/48) / Cepatlah! 'Be quick!' / 'Quickly!'

In the example (24a), the hortative mood can be marked by the changes from -te kudasai that occurs morphologically. While in example (24b), it is necessary to add a word tolong before the verb tulis, so the command sounds more subtle (hortative mood). By adding the word tolong 'please', automatically the marking occurs periphrastically. Thus, the hortative mood in bahasa Indonesia can be marked by additional words tolong.

Last, in example (25a), the imperative mood is marked by the change of -eform, taken from the basic word of isogu, then become isoge. That form functions to express the command roughly. While in (25b), the imperative mood is usually marked by klitika-lah. However, sometimes it is not always so because the original data only shows a word cepat- 
cepat as a contrast of isoge. In the example (25a) and (25b), the meaning are similar. The hortative mood are there, both in example (25a) and (25b), but with the different form.

\section{CONCLUSION}

From the results of the analysis above, the contrastive between Japanese and bahasa Indonesia can be seen from the marking of aspect and mood. The marking of aspect in Japanese occurs morphologically (symbolized as "M") and periphrastically (symbolized as "P"), while in bahasa Indonesia, usually the marking occurs morphologically (M) and periphrastically $(\mathrm{P})$. There were 5 types of aspects that have been discussed in this research, such as perfective and imperfective, resultative, durative, progressive, and habituative.

\section{TABLE I. FIVE ASPECTS}

\begin{tabular}{|c|c|c|c|}
\hline No. & Types of Aspect & Japanese & B. Indonesia \\
\hline 1. & $\begin{array}{l}\text { Perfective } \\
\text { Imperfective }\end{array}$ & $\begin{array}{l}(\mathrm{mou}) \sim \operatorname{shita}[\mathrm{M}] \\
(\text { mada }) \sim \text { te imasen }[\mathrm{M}]\end{array}$ & $\begin{array}{l}\text { sudah }[\mathrm{P}] \\
\text { belum }[\mathrm{P}]\end{array}$ \\
\hline 2. & Resultative & $\begin{array}{l}\text { te imasu }[\mathrm{M}] \\
\sim \text { te arimasu }[\mathrm{M}]\end{array}$ & $\begin{array}{l}\varnothing \\
\text { ter [M] }\end{array}$ \\
\hline 3. & Durative & $\begin{array}{l}\sim \operatorname{masu}[\mathrm{M}] \\
\sim \text { te imasu }[\mathrm{M}]\end{array}$ & $\begin{array}{l}\varnothing \\
\text { akan }[\mathrm{P}] \\
\text { sedang }[\mathrm{P}]\end{array}$ \\
\hline 4. & Progressive & $\begin{array}{l}\text { masu }[\mathrm{M}] \\
\sim \text { te imasu }[\mathrm{M}]\end{array}$ & $\varnothing$ \\
\hline 5. & Habituative & $\begin{array}{l}\text { masu }[\mathrm{M}] \\
\sim \text { te imasu }[\mathrm{M}] \\
\text { (+adverb of time) }\end{array}$ & $\begin{array}{l}\varnothing \\
\text { (+adverb of time) }\end{array}$ \\
\hline
\end{tabular}

Based on table 1 above, aspect in Japanese, can be marked morphologically (M), meanwhile aspect in bahasa Indonesia, can be marked periphrastically $(\mathrm{P})$ or sometimes without any marking/zero mark $(\varnothing)$. But, there is an aspect in bahasa Indonesia that can be marked morphologically (M), it is resultative aspect.

In line with mood, the marking occurs morphologically and periphrastically. There were 5 types of modes that have been discussed in this research such as interrogative, negative, desiderative, irrealist, and imperative-hortative mood.
TABLE II. TYPES OF MOOD

\begin{tabular}{|c|c|c|c|}
\hline No. & Types of Mood & Japanese & B. Indonesia \\
\hline 1. & Interrogative & $\begin{array}{l}\sim \mathrm{ka}[\mathrm{M}] \\
(+\mathrm{QW})\end{array}$ & $\begin{array}{l}\text { question mark (?) } \\
(+ \text { QW) } \\
\text { klitika } \sim \text { kah after } \\
\text { QW }\end{array}$ \\
\hline 2. & Negative & $\begin{array}{l}\sim \text { masen }[\mathrm{M}] \\
\text { F-Present } \\
\sim \text { nai }[\mathrm{M}] \\
\text { I-Present } \\
\sim \text { nakatta }[\mathrm{M}] \\
\text { I-Past }\end{array}$ & $\begin{array}{l}\text { tidak }[\mathrm{P}] \\
\mathrm{F} \\
\text { Present/Past }\end{array}$ \\
\hline 3. & Desiderative & $\begin{array}{l}\text { tai }[\mathrm{M}] \\
\sim \text { jishokei }+ \text { koto ga } \\
\text { dekimasu }[\mathrm{P}] \\
\sim \text { nakereba narimasen } \\
{[\mathrm{M}]}\end{array}$ & $\begin{array}{l}\text { ingin }[\mathrm{P}] \\
\text { dapat }[\mathrm{P}] \\
\text { harus }[\mathrm{P}]\end{array}$ \\
\hline 4. & Irrealist & to itte imashita $[\mathrm{P}]$ & katanya $[\mathrm{P}]$ \\
\hline 5. & $\begin{array}{l}\text { Imperative } \\
\text { Hortative }\end{array}$ & $\begin{array}{l}\text { >meireikei }[\mathrm{M}] \\
\sim \text { te kudasai }[\mathrm{M}]\end{array}$ & $\begin{array}{l}\text { klitika } \sim \text { lah } \\
\text { tolong }[\mathrm{P}]\end{array}$ \\
\hline
\end{tabular}

Based on Table II, mood in Japanese are dominantly marked by morphological changes (M). But there are two types of mood that can be marked by periphrastical changes (P). They are desiderative mood in specific function of showing "a must" meaning and also irrealist mood.

Meanwhile mood in bahasa Indonesia are dominantly marked by periphrastically changes $(\mathrm{P})$. In the table 2 above, some differences can also be found in negative mood. In Japanese's negative mood, there are different form of formal (F) and informal (I) based on the time (present/past), but in bahasa Indonesia's negative mood, there are same form of formal (F) based on the time (present/past).

\section{REFERENCES}

[1] J.W.M. Verhaar, Asas-asas Linguistik Umum. Yogyakarta: Gadjah Mada University, 2012, pp. 239-260.

[2] B. Comrie, Aspect: An Introduction to The Study of Verbal Aspect and Related Problems. Cambridge: Cambridge University Press, 1991.

[3] H. Alwi, Modalitas dalam Bahasa Indonesia. Yogyakarta: Kanisius, 1992.

[4] D. Sutedi, Dasar-dasar Linguistik Bahasa Jepang. Bandung: Humaniora, 2009.

[5] Darjat, “Analisis 'Kala' dan 'Aspek' dalam Bahasa Jepang (Analisis kalimat dalam novel Tokyo Fusen Nikki -Catatan Harian Perahu Layar Tokyo- Karya Midori Nakano)," LITE J. (online) vol.5, no.2, pp.135144, September 2009.

[6] Roni, "Hubungan Qualifier dan Penyambung dalam Frasa Predikat Verba," Jurnal Nihongo. ASPBJI \& The Japan Foundation, vol.4, no.2, pp. 40-49, November 2012.

[7] Aydin Özbek, "Aspect and Modality in Negative Constructions: A Contrastive Analysis of Turkish and Japanese," Journal of Linguistic and Literature, vol.8, no.2, pp. 1-17, July 2011.

[8] Aytemis DEPCI, "A Contrastive Study on Japanese and Turkish Aspect: Focus on -te iru and -(i)yor," The Journal of Academis Social Science Studies (JASSS), vol.6, issue 3, pp.159-189, March 2013. 
[9] Noriko Iwamoto, "Modality and Point of View: A Contrastive Analysis of Japanese Wartime and Peacetime Newspaper Discourse," Edinburgh Workin Papers in Applied Linguistic, no.9, pp. 17-41, 1998.
[10] 3A Corporation, Minna no Nihongo I \& II (Bahasa Jepang dan Terjemahan Bahasa Indonesia). Surabaya: IMAF Press, 2008. 